Arab Univ. J. Agric. Sci., Ain Shams Univ., Cairo, 13(3), 815 - 824, 2005

\title{
THE FEASIBILITY OF USING SOME WHEY PROTEINS CONCENTRATE PREPARATIONS IN MANUFACTURE OF INFANT FORMULA
}

[54]

Fatma, A.M. Hassan' ${ }^{1}$ M.A. Khorshid ${ }^{1}$ and Mona, A.M. Abd El-Gawad ${ }^{1}$

\begin{abstract}
Different types of whey proteins concentrate (WPC) were prepared in Brewaster Dairy pilot plant at Ohio State Univ. USA and used for formulating an infant formula and compared with Alacen 841 (Commercial WPC) as control to select the best WPC preparations which succeed in manufacture of infant formula. Infant formula was prepared with different types of WPC (Alacen 841, UF 5x, UF4x, DF $8 \mathrm{x}$ and DF $4 \mathrm{x}$ ). The ratio of WPC: sodium caseinate was 40: 60. Salt, sucrose, lecithin and vegetable oil were added then homogenized and sterilized after sealing at $121^{\circ} \mathrm{C}$ for 6 minute, cooled in an ice bath and stored at room temperature. Samples were analyzed chemically and organoleptically when fresh and after storage at room temperature for three months. Emulsion volume index (EVI), viscosity, protein solubility, sedimentation and particle size were determined before and after sterilization. Results showed that EVI, viscosity, sedimentation and particle size increased after sterilization than before where as protein solubility take an opposite trend. Emulsion volume index, viscosity, sedimentation and particle sizes were increased after storage at room temperature for three months than fresh. Whereas proteins solubility deceased after storage than fresh. Statistical analysis showed high significant difference $(\alpha 0.05)$ for emulsion volume index, protein solubility, viscosity, particle size and sedimentation.
\end{abstract}

Key words: Whey protein concentrates, Infant formula, Ultrafiltration, Difiltration

\section{INTRODUCTION}

Concentrated infants formula are complex systems and are formulated to resemble the human milk. Since the composition of bovine and human milk are different, whey proteins are utilized in infant's formula to adjust the casein/whey proteins ratio and provide their functionality (e.g. emulsion). The ratio of cow's milk is 80 casein/20 whey proteins, while that of human milk range being 30 40/70-60. Leman and Kinsella (1989) stated that whey proteins generally show lower emulsion capacity than caseinates, whereas emulsions prepared with whey

1- Dairying Department, National Research Center, Dokki, Cairo, Egypt

(Received April 28, 2005)

(Accepted June 8, 2005) 
Arab Univ. J. Agric. Sci., Ain Shams Univ., Cairo, 13(3), 815 - 824, 2005

proteins form more stable emulsions than caseinate. Higher proportion of whey protein was suggested to form more stable emulsion with a ratio of $60 \%$ whey proteins concentrate to $40 \%$ casein Fligner et al (1990). Sterilization of infant formula is necessary in order to meet the requirements of safety and long shelf life. The addition of whey proteins can cause some heat stability problems in the forms of proteins agglomeration, gelation and sedimentation. The emulsion instability is creaming, which can be a major problem in infant formula Miles, (1982). When creaming has occurred, products may not be accepted by consumers. The purpose of this study is to prepare different types of WPC and utilize it in preparing infant formula to select the best WPC preparation which succeed in formulating an infant formula.

\section{MATERIAL AND METHODS}

Freeze dried difiltrated whey proteins concentrate (WPC df4xFD) was prepared in the Brewaster Dairy pilot plant at Ohio State Univ. USA. Lecithin was provided by KERRY Ingredients.

Sucrose and vegetable oil were purchased from the market, cheese starter was provided from Dri-Vac Lactic culture, number $44 \mathrm{Chr}$. Hansens Laboratory, Milwaukee, WI. Cheddar cheese whey was prepared from cow's milk using lactic acid culture and rennet as coagulant.

\section{Preparation of whey proteins concentrate}

WPC was prepared by using procedure of Hwang, (1994) with some modifications. Whey was ultrafiltrated around $45^{\circ} \mathrm{C}$ with an Uf unit equipped with Romicon. UF unit was operated at inlet pressure of $27 \mathrm{psi}$ and an outlet pressure at 12 psi. Fat was separated from whey at $\left(55^{\circ} \mathrm{C}\right)$, followed by pasteurization at $72^{\circ} \mathrm{C}$ for $15 \mathrm{sec}$. Before the UF running the $\mathrm{pH}$ of the whey was adjust to 6.0 by adding citric acid. Whey was concentrated to 5,4 , fold by ultrafiltration and to 8,4 fold by difilteration. The UF running was carried out at $55^{\circ} \mathrm{C}$ to 5 fold. The obtained retentate was ultrafiltrated to 4 fold and adjusted to $\mathrm{pH} 6.0$ with citric acid. Followed by difiltration 8 fold and difiltration to 4 fold. The final products of retentates were freez dried in freez-drying Unit (The Virtis Company, Inc., Gahhdine, NY).

\section{Infant Formula preparation}

* Distilled water (73.8 gm)

Total protein $(4.1 \mathrm{gm})$

(40:60 (WPC: sodium caseinate)

Salt $\quad(0.1 \mathrm{gm})$

Sucrose (14.4 gm)

Lecithin $\quad(0.4 \mathrm{gm})$

Vegetable oil (7.2 gm)

Total $=100 \mathrm{gm}$

Except for oil, the above ingredients were hydrated for at least one hour. The

1- Dairying Department, National Research Center, Dokki, Cairo, Egypt

(Received April 28, 2005)

(Accepted June 8, 2005) 
dispersion and oil were prewarmed to $60^{\circ} \mathrm{C}$ before mixing. The mixture was stirred by a magnetic stirrer and homogenized by an Electric pump 4stage valve homogenizer (HillerØd, Denmark) with $60^{\circ} \mathrm{C}$ water running through a tube that wrapped around the valve. After homogenization, $5 \mathrm{ml}$ sample was placed in a serum bottle and sealed with rubber stopper and aluminum cap. The samples were sterilized at $121^{\circ} \mathrm{C}$ for 6 minutes .After autoclaving of samples, the bottles were cooled in an ice bath and stored at room temperature. Samples were analyzed before and after sterilization as well as after storage at room temperature for three months for protein solubility, viscosity, particle size and sedimentation. Emulsion volume index (EVI) was determined on fresh samples and after storage for 3 months.

\section{Methods of Analysis}

$\mathrm{pH}$ was determined by Oakion $\mathrm{pH}$ a corn series. Protein content was determined by the AOAC, (1980) microkjeldahl method. A tecator ZOZO Digestor and a Tecator Kjeletec auto sampler system 1035 analyzer (perstorp analytical, Inc., Silver Spring, MI) were used.

For viscosity determination a Brook field viscometer LVDVII (Brook field Engineering laboratories, Inc., Stoughton, MA) with a/uL adapter was used. $16 \mathrm{ml}$ of samples were placed in the UL container and viscosity was determined at $25^{\circ} \mathrm{C}$ at $4 \mathrm{rpm}$ for 2 minutes.

Protein solubility was determined by the method of Morr, et al (1985) with some modifications. $1 \%, 3 \%$ and $5 \%$ of different WPC solution were prepared by hydrating WPC for 1 hour and centrifuged $(20.000 \mathrm{xg})$ for 30 minutes by using a sorvall RC-Estates refrigerated supper speed centrifuge (Dupont Instruments, Hoffman Estates, IL). The supernant was filtered and protein content was measured by kjeldhal procedure. Protein solubility was computed from the protein content of the supernatant, as percentage of the total protein content.

Calcium content was determined according to Perkin Elmer Corp (1973) by using perkin-Elmer HGA 2001 controller using a hallo cathode lamp $\left(\mathrm{Ca}^{2+} / \mathrm{Mg}^{2+} / \mathrm{Zn}^{2+}\right)$ at a wave length of $422.7 \mathrm{~nm}$ (air-acetylene flame).

Concentration of $0,1.25,2.5,3.75,5$ and $6.25 \mathrm{mg} \mathrm{Ca}^{+} / \mathrm{ml}$ solutions were used to make a standard curve.

Particle size distribution was measured as described by Bunville, (1984) by Malvern Instrument Ltd., (Worcester shire, WR 141 AT, UK). The particle size distribution of WPC infant formula was determined as follows: after samples preparation, the pump arm was lowered into a beaker filled with approximately $500 \mathrm{ml}$ of distilled water. The stirrer speed was controlled by the pump speed that was set at 1600 . Then few drops of the sample were dropped into the beaker until the measured beam obscuration showed $20 \%$ and $30 \%$.

Sedimentation was determined by using centrifugal method described by Mcdermott, et al (1981).

Emulsion volume index (EVI) was determined according to Mcdermott, et al (1981), as follows; one $\mathrm{ml}$ of the sample was placed in a porcelain plate and mixed with $10 \mu \mathrm{l}$ of oil Red " 0 " and $10 \mu \mathrm{L}$ methylene blue. Microhematocrit capillary tubes were filled with the stained sample and sealed with red stained sealant. Those capillary tubes 
were centrifuged at $13,500 \mathrm{Xg}$ for 30 min. After centrifugation the total length of the sample and length of the emulsion layer were determined. The EVI was calculated by the following equation:

$$
E V I=\frac{(\text { Emulsion length })}{(\text { Total length) }} \times 100
$$

Statistical analysis was according Snedecor and Cochran (1968).

\section{RESULTS AND DISCUSSION}

Table (1), illustrates the effect of using different preparations of WPC and sterilization at $121^{\circ} \mathrm{C}$ for 6 minute one emulsion volume index (EVI) of infant formula. It is clear that EVI increased after sterilization than before in all treatments. The WPC preparation by difiltration to 8 fold (DF8x) had the highest EVI than all treatments whereas WPC (DF4x) had the lowest EVI than all treatments. This may be due to the method of preparation. Fligner et al (1991) showed that sterilization of infant formula results in aggregate of protein which will increase turbidity and possibly falsely predict a stable emulsion and the high value of EVI is desirable. During the formation of emulsion, protein molecules, diffuse to the interface and spread and unfold to form a continuous cohesive film. Low molecular weight emulsifier aids in emulsion formation however, proteins lead to more stable emulsion. Sterilization of infant formula is necessary in order to meet the requirements of safety and long shelf life. The greater stability could also be attributed to increase viscosity. This result is agreeable to the result which in Table, (2) WPC (DF 8x) had a highest viscosity than all treatments. Table, (2) shows the effect of different preparation of WPC on protein solubility \%. It is clear that protein solubility decreased after sterilization than before sterilization in all treatments. These results agree with those of Hassan (2002a). WPC (DF4x) had the lowest protein solubility than all treatments whereas Alacen (841) had the highest protein solubility than all treatments. WPC (DF8x) showed intermediate values. Sterilization often causes denaturation of whey proteins. Whey proteins begins denaturation by heating above $65^{\circ} \mathrm{C}$ followed by aggregation and precipitation. It is known that $\alpha$-la is the most heat resistant whey protein and $\beta-\mathrm{Lg}$ which is the most heatlabile whey protein. Though the denaturation temperature of $\alpha-\mathrm{La}$ is $65^{\circ} \mathrm{C}$, its denaturation is strongly reversible Shu-Wei-Pal (1995). Generally, heating at high temperature results in worse solubility and denaturation and aggregation of proteins. So heat denaturation cause proteins to unfold and increase viscosity and may even result in gelation.

Table, (2) show the effect of different preparations of of WPC on viscosity before and after sterilization at $121^{\circ} \mathrm{C}$ for 6 minute. It could be notice that WPC prepared with difiltration to 8 fold WPC (DF 8x) had highest viscosity begin 1.94 mp than all treatments followed by WPC (DF4x) being $1.89 \mathrm{mp}$ whereas, Alacen 841, commercial WPC had lowest viscosity being $0.89 \mathrm{mp}$. After sterilization the viscosity increased than before in all treatments. These results are in agreement with Kinsella, (1984) who reported that aggregation and precipitation of protein after thermal processing resulted in an increase of 
Using whey protein concentrate in infant formula

viscosity. Also, these results are in agreement with Hassan, (2002b) who found that viscosity of beverages prepared with different whey protein concentrates increased after sterilization than before. The increase in viscosity could enhance greater stability Fligner $\boldsymbol{e t}$ al (1990).

Table, (2) show the effect of different prepared WPC and sterilization at $121^{\circ} \mathrm{C}$ for 6 minute on particle size. Particle size of all different prepared WPC increased 
Arab Univ. J. Agric. Sci., Ain Shams Univ., Cairo, 13(3), 815 - 824, 2005

Table 1. Effect of different prepared whey protein concentrates (WPC) and sterilization at $121^{\circ} \mathrm{C}$ for 6 minute on emulsion volume index (EVI) mm model (infant formula)

\begin{tabular}{|ccc|}
\hline WPC $^{*}$ & Before sterilization & After sterilization \\
\hline Alacen 841 & 0.18 & 0.23 \\
UF5x & 0.22 & 0.25 \\
UF 4x & 0.21 & 0.26 \\
DF 8x & 0.23 & 0.27 \\
DF 4x & 0.17 & 0.26 \\
\hline
\end{tabular}

$\begin{array}{ll}\text { * Alacen } 841 & \text { : Commercial WPC } \\ \text { UF } 5 \mathrm{x} & \text { : Ultrafiltrated to five fold. } \\ \text { UF 4x } & \text { : Ultrafiltrated to four fold. } \\ \text { DF } 8 \mathrm{x} & \text { : Difilterated to eight fold. } \\ \text { DF 4x } & \text { : Difilterated to four fold. }\end{array}$

Table 2. Effect of different prepared whey protein concentrates (WPC) and sterilization at $121^{\circ} \mathrm{C}$ for 6 minute on protein solubility $(\mathrm{P}) \%$, viscosity $(\mathrm{V}) \mathrm{mP}$, particle size (PS) $\mu \mathrm{m}$ and sedimentation (S) mm. of a model infant formula

\begin{tabular}{|ccccccccc|}
\hline WPC $^{*}$ & \multicolumn{3}{c}{ Before sterilization } & \multicolumn{7}{c|}{ After sterilization } \\
\hline & $\begin{array}{c}\mathrm{P} \\
\%\end{array}$ & $\begin{array}{c}\mathrm{V} \\
(\mathrm{mp})\end{array}$ & $\begin{array}{c}\mathrm{PS} \\
(\mu \mathrm{m})\end{array}$ & $\begin{array}{c}\mathrm{S} \\
(\mathrm{mm})\end{array}$ & $\begin{array}{c}\mathrm{P} \\
\%\end{array}$ & $\begin{array}{c}\mathrm{V} \\
(\mathrm{mp})\end{array}$ & $\begin{array}{c}\text { PS } \\
(\mu \mathrm{m})\end{array}$ & $\begin{array}{c}\mathrm{S} \\
(\mathrm{mm})\end{array}$ \\
\hline Alacen 841 & 89.21 & 0.89 & 0.42 & 0.075 & 84.10 & 1.40 & 0.46 & 0.140 \\
UF5x & 77.32 & 1.00 & 0.50 & 0.062 & 73.20 & 2.86 & 0.56 & 0.125 \\
UF 4x & 71.24 & 1.23 & 0.48 & 0.090 & 70.86 & 2.34 & 0.53 & 0.180 \\
DF 8x & 74.62 & 1.94 & 0.65 & 0.085 & 68.30 & 3.54 & 0.70 & 0.190 \\
DF 4x & 7356 & 189 & 077 & 0091 & 7074 & 300 & 075 & 0195
\end{tabular}

1- Dairying Department, National Research Center, Dokki, Cairo, Egypt

(Received April 28, 2005)

(Accepted June 8, 2005) 
Using whey protein concentrate in infant formula

* see Table (1)

Arab Univ. J. Agric. Sci., 13(3), 2005 
Arab Univ. J. Agric. Sci., Ain Shams Univ., Cairo, 13(3), 815 - 824, 2005

after sterilization at $121^{\circ} \mathrm{C}$ for 6 minute temperature for 3 months than than before sterilization. Alacen 841 sample showed the lowest particle size $(\mu \mathrm{m})$ followed by WPC treatments (UF4x) and WPC (UF5x) whereas WPC (DF8x) was intermediat. These results are in agreement with Hassan, (2002a), who found that particle size of WPC in beverages increased after sterilization than before.

Table, (2) indicates the effect of using different prepared WPC on sedimentation. It is clear that UF WPC to 5 folds (UF5x) had low sedimentation whereas WPC difiltrated to 8 folds had intermediate sedimentation. On the other hand WPC difilterated to four folds had the highest sedimentation. Also sedimentation was increased after sterilization than before in all treatments. These results agree with Hassan, (2002b) who found that sedimentation of beverages prepared with different WPC increased after sterilization than before. This may be due to the intensive effect of heating on whey proteins denaturation. Table, (3) summarize the organoleptic properties of infant formula prepared with different WPC. Infant formula prepared with WPC difiltration to eight folds had gained the highest scores for appearance, taste and flavour followed by WPC difiltration to four folds and Alacen 841 (commercial WPC). On the other hand WPC ultrafiltrated to five folds had the lowest score for appearance, taste and flavour. Table, (4) show the effect of storage at room temperature on emulsion value index (EVI). It is clear that EVI increased after storage at room

1- Dairying Department, National Research Center, Dokki, Cairo, Egypt

(Received April 28, 2005)

(Accepted June 8, 2005) 
Using whey protein concentrate in infant formula

before storage in all treatments. The infant formula prepared with WPC (DF8x) had the highest EVI than all treatments whereas Alacen 841 had the lowest EVI. These results agree with the results of Table, (2). Where increasing of viscosity led to increase EVI.

Table, (5) shows the effect of storage on protein solubility. It is clear that protein solubility decreased after storage at room temperature for 3 months. Table, (5) illustrates the effect of storage at room temperature on viscosity (mp). It could be notice that viscosity increased after storage than before in all treatments this may be due to the effect of storage. Table, (5) summarized the effect of storage on particle size (PS) $\mu \mathrm{m}$. PS which increased after storage than before (Table, 2) in all treatments, summarized the effect of storage on particle size (PS) $(\mu \mathrm{m})$ which increased after storage than before in all treatments. Regarding sedimentation it increased after storage than before in all treatments. Table, (6) indicate the effect of storage at room temperature on organoleptic properties of infant formula containing different WPC treatments. It was clear that appearance, taste and flavour decreased after storage than before in all treatments.

\section{CONCLUSION}

Finally it could be conduced that, whey proteins concentrate (WPC), (DF $8 \mathrm{x}$ ) was the best treatment that enhance the functionality of WPC and is successful in preparing infant formula. 
Arab Univ. J. Agric. Sci., Ain Shams Univ., Cairo, 13(3), 815 - 824, 2005

Table 3. Organoleptic properties of infant formula treatments prepared with different prepared whey protein concentrates (WPC)

\begin{tabular}{|ccccc|}
\hline WPC $^{*}$ & $\begin{array}{c}\text { Appearance } \\
(10)\end{array}$ & $\begin{array}{c}\text { Taste } \\
(60)\end{array}$ & $\begin{array}{c}\text { Flavour } \\
(30)\end{array}$ & $\begin{array}{c}\text { Total } \\
(100)\end{array}$ \\
\hline Alacen & 8 & 53 & 26 & 87 \\
841 & 6 & 22 & 24 & 80 \\
UF5x & 7 & 51 & 23 & 81 \\
UF4x & 9 & 55 & 27 & 91 \\
DF 8x & 8 & 54 & 25 & 87 \\
DF 4x & 8 & & & \\
\hline
\end{tabular}

* See Table (1)

Table 4. Effect of storage at room temperature of infant formula with different prepared whey protein concentrates (WPC) on emulsion volume index (EVI) $\mathrm{mm}$

\begin{tabular}{|ccc|}
\hline WPC* & Fresh & $\begin{array}{c}\text { After 3 } \\
\text { months }\end{array}$ \\
\hline Alacen 841 & 0.23 & 1.75 \\
UF5x & 0.25 & 1.90 \\
UF 4x & 0.26 & 1.59 \\
DF 8x & 0.27 & 2.13 \\
DF 4x & 0.26 & 1.98 \\
\hline
\end{tabular}

* See Table (1)

Table 5. Effect of storage at room temperature on protein solubility $(\mathrm{P}) \%$, viscosity (V)mp, particle size (PS) $\mu \mathrm{m}$ and sedimentation (S) (mm.) of a model infant formula

\begin{tabular}{|ccccc|}
\hline WPC* & \multicolumn{4}{c|}{ Three months } \\
\cline { 2 - 5 } & P $\%$ & V $(\mathrm{mp})$ & PS $(\mu \mathrm{m})$ & $\mathrm{S}(\mathrm{mm})$ \\
\hline Alacen 841 & 80.32 & 3.60 & 1.86 & 0.321 \\
UF5x & 69.35 & 3.90 & 1.90 & 0.300
\end{tabular}

1- Dairying Department, National Research Center, Dokki, Cairo, Egypt

(Received April 28, 2005)

(Accepted June 8, 2005) 
Using whey protein concentrate in infant formula

* See Table (1)

Table 6. Effect of storage at room temperature on organoleptic properties of a model infant formula

\begin{tabular}{|ccccc|}
\hline WPC* & \multicolumn{4}{c|}{ Three months } \\
\cline { 2 - 5 } & $\begin{array}{c}\text { Appearance } \\
(10)\end{array}$ & $\begin{array}{c}\text { Taste } \\
(60)\end{array}$ & $\begin{array}{c}\text { Flavour } \\
(30)\end{array}$ & $\begin{array}{c}\text { Total } \\
(100)\end{array}$ \\
\hline Alacen 841 & 7 & 51 & 24 & 82 \\
UF5x & 5 & 50 & 21 & 76 \\
UF 4x & 6 & 48 & 20 & 72 \\
DF 8x & 8 & 53 & 25 & 86 \\
DF 4x & 7 & 50 & 22 & 79 \\
\hline
\end{tabular}

* See Table (1)

\section{REFERENCES}

AOAC (1980). Official Methods of Analysis, $13^{\text {th }} \mathbf{E d}$. Association of Official Analytical Chemist. Washington, DC. Bunville, L.G. (1984). Commercial instrumentation for particle size analysis. In: Modern Methods of Particle SizeAnalysis p. 10 (Barth, H.G. ed.), John Wiley and Sons, New York.

Fligner, K.L.; M.A. Fligner and M.E. Mangino (1990). The effects of compositional factors on the short-term physical stability of a concentrated infant formula. Food Hydrocolloids, 4 (2): 95 101.

Fligner, K.L.; M.A. Fligner and M.E. Mangino (1991). Accelerated tests for predicting long-term creaming stability of infant formula emulsion system. Food Hydrocollids 5(3): 269-280.

Hassan, F.A.M. (2002a). Effect of $\mathrm{pH}$ of preparing of whey protein concentrate
(WPC) on its functionality Model (beverage). Annals Agric. Sci., Ain Shams Univ., Cairo, 47 (1): 301-311. Hassan, F.A.M. (2002b). Production of whey protein concentrates (WPC) in pilot plant and utilizing it for preparing beverages. Annals Agric., Ain Shams Univ., Cairo, 47(1): 313-323.

Hwang, C.S. (1994). Decreasing the Gelation Temperatures of Whey Protein Concentrate to Increase Functionality pp. 30-31. Ph.D. thesis, The Ohio State Univ., Columbus.

Kinsella, J.E. (1984). Milk proteins: Physical and Functional Properties. $C R C$ Crit. Rev. Food Sci. Nutr., 21: 197-202. Leman, J. and J.E. Kinsella (1989). Surface activity, film formation and emulsifying properties of milk proteins. CRC Crit. Rev. Food Sci. Nutr., 28: 115120.

Mcdermott, R.L.; W.J. Harper and R. Whitley (1981). Centrifugal method for 
Arab Univ. J. Agric. Sci., Ain Shams Univ., Cairo, 13(3), 815 - 824, 2005

characterization of salad dressing emulsions. Food Techn., 5: 81-87.

Miles, J.P. (1982). Infant formula physical stability. J. Assoc. Off. Anal.

Chem., 56(6): 1482-1490.

Morr, C.V.; B. German; J.E.R.

Kinsella; J.M. Regenstein; J.P.

Vanburen; A. Kilara; B.A. Lewis and M.E. Mangino (1985). Collaborative study to develop a standardized food protein solubility procedure, $\boldsymbol{J}$. Food

Science 50: 1715-1718.

Perkin-EImer Corp. (1973). Analytical

Methods for Atomic Absorption

Spectrophotometry. pp. 205-207. The

Perkin-Elmer Corporation, Norwalk, C.T.
Shu-Wei-Pal (1995). Production of

Emulsion Stability and Determination of the Factors Affecting Emulsion Stability of Whey Protein Concentrates in Concentrated Infant Formula. pp. 182186. Ph.D. Thesis, the Ohio State Univ., Columbus.

Snedecor, G.W. and W.G. Cochran (1968). Statisticals Methods $7^{\text {th }}$ Ed. The Lowa State University Press. Ames, Iowa, USA.

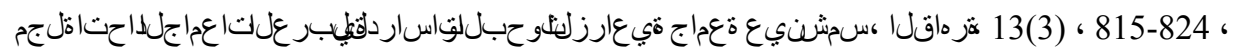
2005

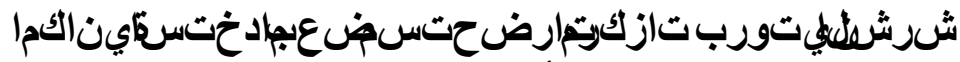

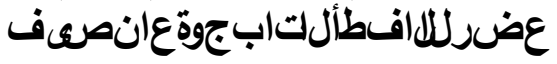

]54[

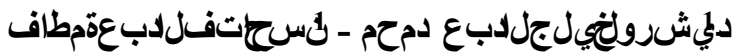

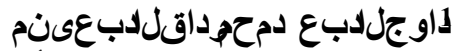

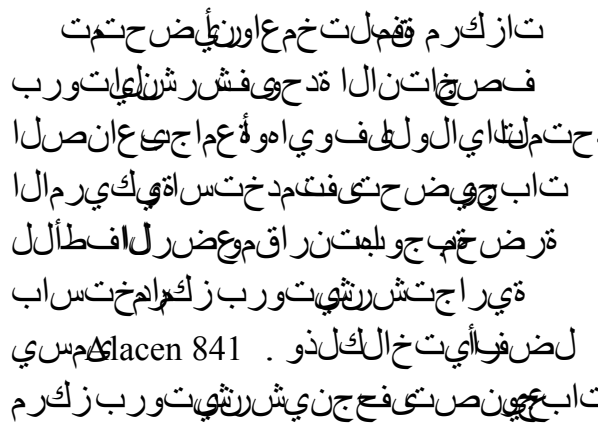

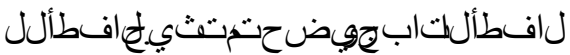

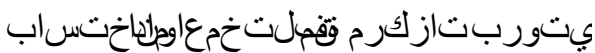

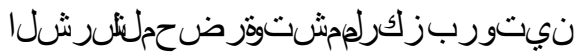

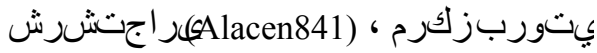

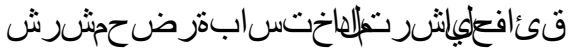

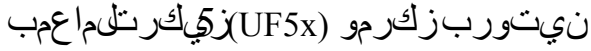

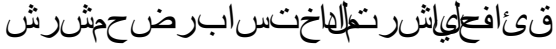

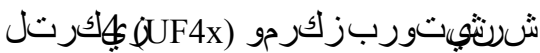

1- Dairying Department, National Research Center, Dokki, Cairo, Egypt

(Received April 28, 2005)

(Accepted June 8, 2005) 
Arab Univ. J. Agric. Sci., Ain Shams Univ., Cairo, 13(3), 815 - 824, 2005

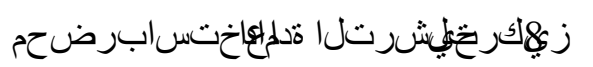

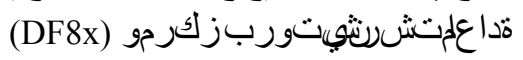

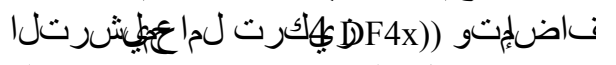

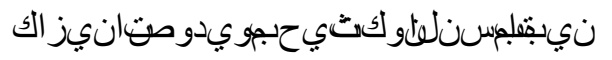

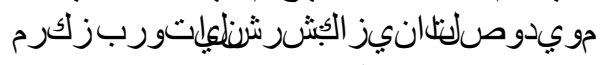

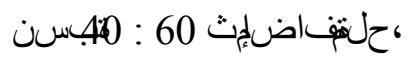

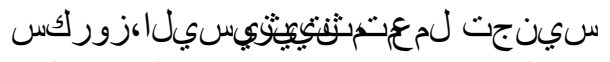

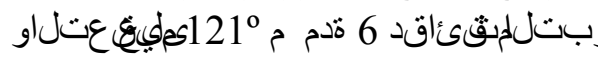

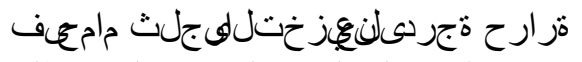

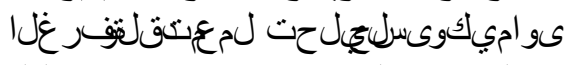

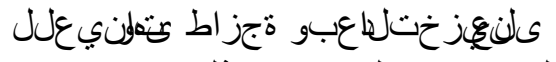

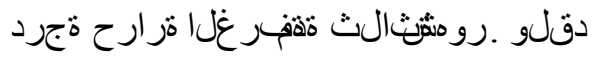

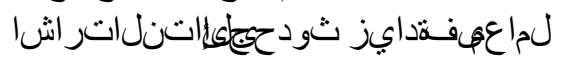

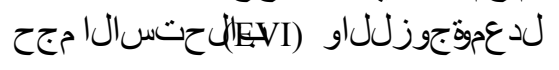

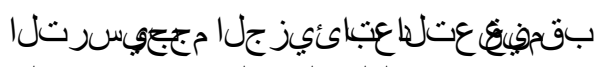

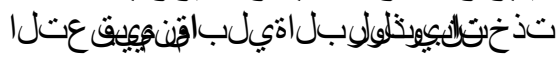

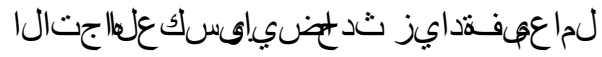

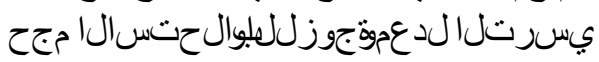

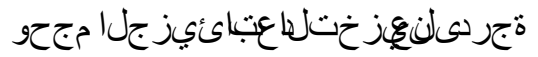

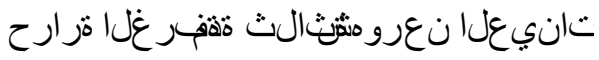

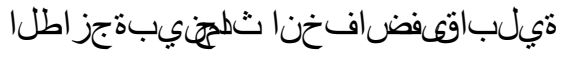

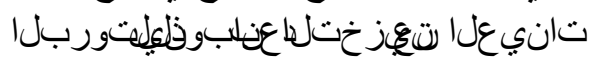

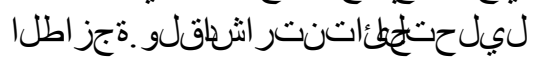

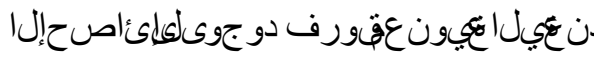

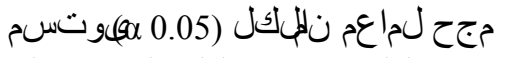
بوظفيلهتور بثليلباقوةجوزل نلبلوال حتسال

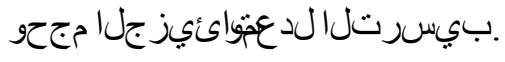

نارهم دمجأبيدلا لامج د:لْميك

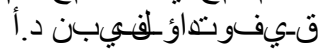

1- Dairying Department, National Research Center, Dokki, Cairo, Egypt 